\title{
Model for Measuring benefit of Government IT Investment using Fuzzy AHP
}

\author{
Prih Haryanta $^{1}$, Azhari Azhari ${ }^{2}$, Khabib Mustofa ${ }^{3}$ \\ Department of Computer Science and Electronics \\ Faculty of Mathematic and Natural Sciences \\ Universitas Gadjah Mada, Yogyakarta, Indonesia
}

\begin{abstract}
Information Technology (IT) has become a mandatory for every organization including government. Investment on IT can help government to deliver services to the citizen. Every IT investment should give the maximum result. Measurement for the benefit of IT investment is needed to make sure that it has deliver the missions and goals. There are plenty models for measuring the feasibility of an IT investment before the implementation. But there are still few models to measure the IT investment after implementation. This paper proposes a model to measure the benefit of an IT investment after implementation, especially in government organizations. The model uses generic IS/IT business value category which consists of 13 categories and 73 sub-categories. Each category will be weighted according to organization preference using Fuzzy Analitic Hierarchy Process (FAHP). This model is applied to measure IT investments in the Ministry of Finance of the Republic of Indonesia, named SPAN and SAKTI applications. The weighted benefit score of SPAN is $\mathbf{7 6 . 3 9 \%}$, while the original score is $\mathbf{7 5 . 8 9 \%}$. The weighted benefit score of SAKTI is $\mathbf{6 8 . 0 8 \%}$, while the original score is $67.33 \%$. The differences between the original score and weighted score indicate that the model accommodates the organization's preference in the evaluation.
\end{abstract}

Keywords-IT investment; government investment; ex-post evaluation; benefit creation; fuzzy AHP; analytic hierarchy process

\section{INTRODUCTION}

The use of Information Technology (IT) will increase the atmosphere of openness and transparency [1]. Thus, IT can be used by the Government to deliver transparent and accountable services. Investment in IT by Government is needed to support the organization. The IT investment that has been implemented by the government needs to be evaluated as an embodiment of accountable governance. According to the IT governance framework, The Control Objectives for Information and Related Technology (COBIT) version 5, in the EDM02 process -Ensure Benefits Delivery, organizations must be able to ensure that IT benefits have actually been achieved and are received by all stakeholders.

After an investment being implemented, there is a need to measure that the benefit of investment has been delivered to the stakeholder. The measurement problem is a significant factor that becomes an obstacle in evaluation [2][3]. It is difficult to identify the benefits in ex-post evaluations [4]. That is because of the different systems used by various business areas so that the benefits of each business area can be varied. The evaluation is complicated because the definition of success is unclear and varies from one organization to another [5]. The

This research was supported by the Ph.D. grant of the Indonesia endowment fund for education (LPDP), Ministry of Finance of The Republic of Indonesia. unclear definition of benefit/value makes an imbalance between theory and practice [6].

Ex-post evaluation models for government IT investments are still very limited in number. Some ex-post IT investment evaluation models used by governments in the world like Social Return on Investment (SROI), Balanced E-Government Index (BEGIX), Public Sector Value Model (PSV), Performance Reference Model (PRM), Interchange of Data between Administration Value of Investment (IDA VOI), Method of Analysis and Value Enhancement (MAREVA), EGov Economics Projects (eGEP) [7][8]. Some of the above models (SROI, BEGIX, IDA VOI, MAREVA) use financialbased to measure the benefit/value creation. While for government institutions, it is not always about financial benefit. A literature review on Information and Communication Technologies (ICT) project evaluation by AL-Ghamdi et al [9] found that the post implementation evaluation approach of the ICT project in common practice are assessing non-financial ICT business values. The PRM model focuses more on organizational performance in general and not on the impact of IT investment results. Although the PSV model does not measure the value of money, it does not show the specific value obtained from the IT investment. While the eGEP model is very broad in scope, its measurement is not suitable for measuring a single IT investment by the government. Setiawan et al [10] proposed a hybrid method for evaluating the performance of ICT projects. Although the methods can be used to evaluate the performance of ICT projects, it cannot determine what benefits are created from the ICT projects being evaluated.

Therefore, there is a need to develop a new ex-post evaluation method that can show the benefit/value of an IT investment, especially in government organizations. It should overcome the problem of benefit differences in various organizations. Also, the method should accommodate the organization's preference in the evaluation. This study proposed a model for identifying benefit creation of an IT investment in government organizations. The benefit created will be scored and weighted according to decision makers in the organization.

This paper is divided into six sections: the first section is the introduction, the second and third sections are the literature review, the fourth section is the research methodology, the fifth sections present the result and discussion, and the last section present the conclusions generated from this research. 


\section{GENERIC IS/IT Business VALUE TEMPLATE}

The generic IS/IT Business value template was proposed by Ranti [11]. The IS/IT business value template consists of 13 benefit categories and 73 benefit sub-categories, they are:

1) Reducing Cost of (traveling cost, staff/operator/ employee cost, meeting cost, service failure cost, application development cost, delivery cost, training cost per employee, returning cost for incorrect delivery, cost of money, office supplies and printing cost, subscription cost of certain reading materials or subscription cost per employee, space rental cost, device rental cost, inventory cost, research failure cost).

2) Increasing Productivity caused by (restructuring job function, accelerating mastering product knowledge, ease of analysis, increasing employee satisfaction).

3) Accelerating Process of (production process, stock procurement process, report making process, data preparation process, order checking process, debt payment process, transaction process, decision-making process).

4) Reducing Risk of (price miscalculation, unrecoverable claim, inventory lost, rejected goods, data lost, incorrect data, penalty, losing potential employee, forgery, administration fraud, incorrect payment, asset mismanagement).

5) Increasing Revenue caused by (increasing business capacity, increasing report quality, increasing customer trust, widening market segment, increasing other incomes).

6) Increasing Accuracy of (billing, analysis, data, planning, decision).

7) Accelerating Cash-in caused by (accelerating billing dispatching).

8) Increasing External Services of (reducing order cancellation, knowing customer's problems, adding a point of services, personalized services, customer satisfaction).

9) Increasing Image caused by (increasing service quality, offering substantial discounts, complying with regulations, using branded systems).

10)Increasing Quality of (better supplier/vendor management, work result, services, products).

11)Increasing Internal Services of (shared services, matching employee's right and responsibility, employee services, proper schedule, and training material).

12)Increasing Competitive Advantage caused by (forming business alliances, accelerating the execution of new business opportunities, increasing switching costs).

13)Avoiding Cost of (reserved fund, maintenance cost, lost and delay cost).

This template could be used to overcome the problem of benefit differences in various organizations. The generic IS/IT Business value template will be used as a base for measurement.

\section{FUZZY AHP}

Analytic Hierarchy Process (AHP) is a method proposed by Saaty [12][16] for selecting alternatives using distinct criteria. The AHP method breaks a complex and unstructured problem into several components in a hierarchical arrangement. The decision-maker makes a pairwise comparison between criteria. This method can be used for weighting the criteria for decision making. AHP deals with a crisp number to represents the judgment by the decision-maker. The intensity scale of importance converted into a number for computation.

Fuzzy AHP (FAHP) method proposed by Laarhoven and Pedrycz [13] is an extension of AHP using fuzzy concept. The scale of importance is represented in fuzzy using Triangular Fuzzy Number (TFN) (Table I). FAHP could deal with subjective judgment in making priorities. Sehra et al. demonstrated the different results of software quality model selection using AHP and FAHP [14].

Using Extend Analysis by Chang [15], Fuzzy AHP technique is divided into several steps:

1) Creating a pairwise comparison matrix between categories in the TFN scale.

2) Calculating the fuzzy synthetic extents $\left(\tilde{S}_{x}\right)$ of the above matrix on category $x$ with the equation:

$\left(\widetilde{S}_{x}=\sum_{y=1}^{n} \widetilde{C}_{x y} \otimes\left[\sum_{k=1}^{n} \sum_{y=1}^{n} \widetilde{C}_{k y}\right]^{-1} ; \mathrm{x}=1,2, \ldots, \mathrm{n}\right.$

Where $\otimes$ denotes the extended multiplication of two fuzzy numbers, $n$ is the size of the pairwise comparison matrix between categories, and $k$ is a combination of criteria from line $i$ where $i=1$ to $n$.

$\sum_{y=1}^{n} \tilde{C}_{x y}=\left(\sum_{y=1}^{n} l_{x y}, \sum_{y=1}^{n} m_{x y}, \sum_{y=1}^{n} u_{x y}\right) ; \mathrm{x}=1,2, \ldots, \mathrm{n}$

where $l$ is the lower bound, $m$ is the middle bound, $u$ is the upper bound.

$\left[\sum_{k=1}^{n} \sum_{y=1}^{n} \tilde{C}_{k y}\right]^{-1}=\left[\frac{1}{\sum_{k=1}^{n} \sum_{y=1}^{n} u_{k y}}, \frac{1}{\sum_{k=1}^{n} \sum_{y=1}^{n} m_{k y}}, \frac{1}{\sum_{k=1}^{n} \sum_{y=1}^{n} l_{k y}}\right]$

$\sum_{k=1}^{n} \sum_{y=1}^{n} \tilde{C}_{k y}=$

$\left(\sum_{k=1}^{n} \sum_{y=1}^{n} l_{k y}, \sum_{k=1}^{n} \sum_{y=1}^{n} m_{k y}, \sum_{k=1}^{n} \sum_{y=1}^{n} u_{k y}\right)=$

$\left[\left(\sum_{y=1}^{n} l_{1 y}, \sum_{y=1}^{n} m_{1 y}, \sum_{y=1}^{n} u_{1 y}\right)+\cdots+\right.$

$\left.\left(\sum_{y=1}^{n} l_{n y}, \sum_{y=1}^{n} m_{n y}, \sum_{y=1}^{n} u_{n y}\right)\right]$

3) Comparing the fuzzy synthetic extents $\left(\tilde{S}_{x}\right)$ of one category with another fuzzy synthetic extents category $\left(\tilde{S}_{y}\right)$, which is called as degree of possibility with equation:

$V\left(\tilde{S}_{x} \geq \tilde{S}_{y}\right)\left\{\begin{array}{c}0, \text { if } m_{x} \geq m_{y} \\ 1, \text { if } l_{y} \geq u_{x} \\ \frac{l_{y}-u_{x}}{\left(m_{x}-u_{x}\right)-\left(m_{y}-l_{y}\right)}, \text { otherwise }\end{array}\right.$

Where $V\left(\tilde{S}_{x} \geq \tilde{S}_{y} \mid \mathrm{y}=1, \ldots, \mathrm{n}\right) ; \mathrm{y} \neq \mathrm{x}$

4) Determining the minimum degree of possibility of $V\left(\tilde{S}_{x} \geq \tilde{S}_{y}\right)$

$d^{\prime}\left(A_{x}\right)=\min V\left(\tilde{S}_{x} \geq \tilde{S}_{y}\right)$

Then the weight vector ( $W^{\prime}$ ) is given by

$W^{\prime}=\left(d^{\prime}\left(A_{1}\right), d^{\prime}\left(A_{2}\right), \ldots, d^{\prime}\left(A_{n}\right)\right)^{T}$

Where $A_{1}(i=1,2, \ldots, n)$ are $n$ elements. 
TABLE. I. TRIANGULAR FUZZY NUMBER

\begin{tabular}{|l|l|l|}
\hline Linguistic Variable & Positive TFN & Positive Reciprocal TFN \\
\hline Extremely Strong (ES) & $(9,9,9)$ & $(1 / 9,1 / 9,1 / 9)$ \\
\hline Intermediate value & $(6,8,9)$ & $(1 / 9,1 / 8,1 / 6)$ \\
\hline Very Strong (VS) & $(5,7,9)$ & $(1 / 9,1 / 7,1 / 5)$ \\
\hline Intermediate value & $(4,6,8)$ & $(1 / 8,1 / 6,1 / 4)$ \\
\hline Strong (S) & $(3,5,7)$ & $(1 / 7,1 / 5,1 / 3)$ \\
\hline Intermediate value & $(2,4,6)$ & $(1 / 6,1 / 4,1 / 2)$ \\
\hline Moderately Strong (MS) & $(1,3,5)$ & $(1 / 5,1 / 3,1)$ \\
\hline Intermediate value & $(1,2,4)$ & $(1 / 4,1 / 2,1)$ \\
\hline Equally Strong (EqS) & $(1,1,1)$ & $(1,1,1)$ \\
\hline
\end{tabular}

5) Then the normalized importance weight vector $W$ of the pairwise comparison are:

$W=\left(d\left(A_{1}\right), d\left(A_{2}\right), \ldots, d\left(A_{n}\right)\right)^{T}$

where $W$ is a nonfuzzy number that represents the priority weights of an attribute or an alternative over another.

\section{RESEARCH METHODOLOGY}

The proposed model is for measuring the benefit generated by an IT investment in government organizations. To identify the benefit, this model is using the Generic IS/IT Business Value Template. The use of the template is intended to overcome the problem of benefit differences in various organizations. Secondly, this model will use Fuzzy AHP to weighting the benefit category. The weighting process is needed to accommodate the organization's preference.

The first step of the proposed model is to determine the categories and subcategories of business benefits that are created with IT investment. This step will be carried out by distributing questionnaires to stakeholders involved in implementing IT investments. With this questionnaire method, we will get benefit categories and subcategories that have contributed to the creation of benefit with IT investment. In the survey respondents are choosing the benefit creation from each benefit sub-category based on their experiences. Respondents fill based on personal experience in the field by following intuition, experience, data, information and critical level possessed by the assessor [17]. Filling in the benefit creation by using a scale in lingual form with the following percentage ranges:

a) Very high benefits $((80-100 \%])$

b) High benefits ((60-80\%])

c) Medium benefits ((40-60\%])

d) Low benefits ((20-40\%])

e) Very low benefits $((0-20 \%])$

f) No benefits created $(0 \%)$

The results of the questionnaire then processed to obtain the benefit score. The score of benefit categories is the average score of the benefit sub-categories from particular categories. The score of each benefit categories then multiplied by the weight of the categories. The weight of each benefit categories is made by decision-maker using pairwise comparison between the categories. The result of comparison is then processed by the Fuzzy AHP method to get the importance weight of each benefit category. The final score of benefit creation is the sum of the weighted values of each benefit category.

To validate the proposed model, the model has been used to evaluating two IT investment in the Ministry of Finance of the Republic of Indonesia (MoF), i.e.

1) Sistem Perbendaharaan dan Anggaran Negara (SPAN) (State Treasury and Budget Application System).

2) Sistem Aplikasi Keuangan Tingkat Instansi (SAKTI) (Institution-level Financial Application System).

SPAN is an IT investment made by MoF to integrate and centralize the financial management information system in Indonesia. It replaced the old system which was distributed across the country. SAKTI is also an IT investment made by MoF to integrate many financial application in the operating ministries. SPAN and SAKTI application now support the new financial system for the Government of the Republic of Indonesia.

\section{RESULT AND DISCUSSION}

To collect the opinion from the stakeholder, questionnaire has been given to the user to measure the benefit creation based on their experience. The questionnaire is based on the Generic IS/IT Business value template. For weighting the category, the decision-maker in the organization makes a pairwise comparison between the benefit categories. There are 13 benefit categories, i.e reducing cost (C1), increasing productivity (C2), accelerating process (C3), reducing risk (C4), increasing revenue (C5), increasing accuracy (C6), accelerating cash-in (C7), increasing external services (C8), increasing image (C9), increasing quality (C10), increasing internal services (C11), increasing competitive advantage (C12), and avoiding cost (C13). The result of the pairwise comparison in the TFN scale is presented in Table II.

Using extent analysis by Chang (equation 1 to 8), the result of importance weight vectors after normalization is presented in Table III. The weight value of the benefit category summarized and presented in Table IV. The weight of the benefit category then used for calculating the total benefit created from the IT investment.

The questionnaire was given to the SPAN and SAKTI applications users. There are 30 respondents for each application. The score of each benefit category is obtained from the average score of sub-categories benefit in the same category. The benefit score then multiplied by the weight of the benefit category. The final benefit score is the sum of the weighted score of all benefit categories. The result is shown in Table V and Table VI.

The result of SPAN investment, the total weighted benefit score $(76.39 \%)$ is higher than the original score $(75.89 \%)$. This indicates that some benefit categories with high priority has a higher score among others. On the other hand, the top priority benefit category (reducing risk) has a score of $78.11 \%$ that categorized as a high benefit. And the least score of benefit category belongs to benefit "increasing competitive advantage" which is the $7^{\text {th }}$ priority out of 13 . 
TABLE. II. PAIRWISE COMPARISON IN TFN

\begin{tabular}{|c|c|c|c|c|c|c|c|c|c|c|c|c|c|c|c|c|c|c|c|c|c|c|c|c|c|c|c|c|c|c|c|c|c|c|c|c|c|c|c|}
\hline & \multicolumn{3}{|c|}{$\mathrm{C} 1$} & \multicolumn{3}{|c|}{ C2 } & \multicolumn{3}{|c|}{ C3 } & \multicolumn{3}{|c|}{$\mathrm{C} 4$} & \multicolumn{3}{|c|}{ C5 } & \multicolumn{3}{|c|}{ C6 } & \multicolumn{3}{|l|}{ C7 } & \multicolumn{3}{|c|}{ C8 } & \multicolumn{3}{|l|}{ C9 } & \multicolumn{3}{|c|}{$\mathrm{C} 10$} & \multicolumn{3}{|c|}{$\mathrm{C} 11$} & \multicolumn{3}{|c|}{$\mathrm{C} 12$} & \multicolumn{3}{|c|}{$\mathrm{C} 13$} \\
\hline & 1 & $\mathrm{~m}$ & $\mathrm{u}$ & 1 & $\mathrm{~m}$ & $\mathrm{u}$ & 1 & $\mathrm{~m}$ & $\mathrm{u}$ & 1 & $\mathrm{~m}$ & $\mathrm{u}$ & 1 & $\mathrm{~m}$ & $\mathrm{u}$ & 1 & $\mathrm{~m}$ & $\mathrm{u}$ & 1 & $\mathrm{~m}$ & $\mathrm{u}$ & 1 & $\mathrm{~m}$ & $\mathrm{u}$ & 1 & $\mathrm{~m}$ & $\mathrm{u}$ & 1 & $\mathrm{~m}$ & $\mathrm{u}$ & 1 & $\mathrm{~m}$ & $\mathrm{u}$ & 1 & $\mathrm{~m}$ & $\mathrm{u}$ & 1 & $\mathrm{~m}$ & $\mathrm{u}$ \\
\hline $\begin{array}{l}\text { C } \\
1\end{array}$ & 1 & 1 & 1 & 1 & 3 & 5 & 1 & 3 & 5 & 1 & 3 & 5 & 1 & 1 & 1 & 1 & 1 & 1 & 1 & 3 & 5 & 1 & 1 & 1 & 1 & 3 & 5 & 1 & 1 & 1 & 1 & 3 & 5 & 1 & 1 & 1 & 1 & 1 & 1 \\
\hline $\begin{array}{l}\mathrm{C} \\
2\end{array}$ & $\begin{array}{l}0 \\
2\end{array}$ & $\begin{array}{l}0, \\
33\end{array}$ & 1 & 1 & 1 & 1 & 1 & 1 & 1 & 1 & 1 & 1 & 1 & 1 & 1 & 1 & 1 & 1 & 1 & 1 & 1 & 1 & 3 & 5 & 1 & 1 & 1 & 1 & 1 & 1 & 1 & 1 & 1 & 1 & 3 & 5 & 1 & 1 & 1 \\
\hline $\begin{array}{l}C \\
3\end{array}$ & $\begin{array}{l}0 \\
2\end{array}$ & $\begin{array}{l}0, \\
33\end{array}$ & 1 & 1 & 1 & 1 & 1 & 1 & 1 & 1 & 1 & 1 & 1 & 1 & 1 & 1 & 1 & 1 & 1 & 3 & 5 & 1 & 3 & 5 & 1 & 3 & 5 & 1 & 3 & 5 & 1 & 3 & 5 & 1 & 3 & 5 & 1 & 3 & 5 \\
\hline $\begin{array}{l}\mathrm{C} \\
4\end{array}$ & $\begin{array}{l}0 \\
2\end{array}$ & $\begin{array}{l}0, \\
33\end{array}$ & 1 & 1 & 1 & 1 & 1 & 1 & 1 & 1 & 1 & 1 & 1 & 3 & 5 & 1 & 3 & 5 & 1 & 3 & 5 & 1 & 3 & 5 & 1 & 3 & 5 & 1 & 3 & 5 & 1 & 3 & 5 & 1 & 3 & 5 & 1 & 3 & 5 \\
\hline $\begin{array}{l}C \\
5\end{array}$ & 1 & 1 & 1 & 1 & 1 & 1 & 1 & 1 & 1 & $\begin{array}{l}0, \\
2\end{array}$ & $\begin{array}{l}0,3 \\
3\end{array}$ & 1 & 1 & 1 & 1 & 1 & 1 & 1 & 1 & 1 & 1 & 1 & 1 & 1 & 1 & 1 & 1 & 1 & 1 & 1 & 1 & 3 & 5 & 1 & 1 & 1 & 1 & 3 & 5 \\
\hline $\begin{array}{l}\text { C } \\
6\end{array}$ & 1 & 1 & 1 & 1 & 1 & 1 & 1 & 1 & 1 & $\begin{array}{l}0, \\
2\end{array}$ & $\begin{array}{l}0,3 \\
3\end{array}$ & 1 & 1 & 1 & 1 & 1 & 1 & 1 & 1 & 3 & 5 & 1 & 1 & 1 & 1 & 1 & 1 & 1 & 1 & 1 & 1 & 1 & 1 & 1 & 3 & 5 & 1 & 3 & 5 \\
\hline $\begin{array}{l}\text { C } \\
7\end{array}$ & $\begin{array}{l}0 \\
2 \\
2\end{array}$ & $\begin{array}{l}0, \\
33\end{array}$ & 1 & 1 & 1 & 1 & $\begin{array}{l}0, \\
2\end{array}$ & $\begin{array}{l}0, \\
33\end{array}$ & 1 & $\begin{array}{l}0, \\
2\end{array}$ & $\begin{array}{l}0,3 \\
3\end{array}$ & 1 & 1 & 1 & 1 & $\begin{array}{l}0, \\
2\end{array}$ & $\begin{array}{l}0,3 \\
3\end{array}$ & 1 & 1 & 1 & 1 & 1 & 1 & 1 & 1 & 3 & 5 & 1 & 1 & 1 & 1 & 1 & 1 & 5 & 7 & 9 & 1 & 1 & 1 \\
\hline $\begin{array}{l}\text { C } \\
8\end{array}$ & 1 & 1 & 1 & $\begin{array}{l}0, \\
2\end{array}$ & $\begin{array}{l}0, \\
33\end{array}$ & 1 & $\begin{array}{l}0, \\
2\end{array}$ & $\begin{array}{l}0, \\
33\end{array}$ & 1 & $\begin{array}{l}0, \\
2\end{array}$ & $\begin{array}{l}0,3 \\
3\end{array}$ & 1 & 1 & 1 & 1 & 1 & 1 & 1 & 1 & 1 & 1 & 1 & 1 & 1 & 1 & 1 & 1 & 1 & 1 & 1 & 1 & 1 & 1 & 1 & 1 & 1 & 1 & 1 & 1 \\
\hline $\begin{array}{l}\text { C } \\
9\end{array}$ & $\begin{array}{l}0 \\
\text {, }\end{array}$ & $\begin{array}{l}0, \\
33\end{array}$ & 1 & 1 & 1 & 1 & $\begin{array}{l}0, \\
2\end{array}$ & $\begin{array}{l}0, \\
33\end{array}$ & 1 & $\begin{array}{l}0, \\
2\end{array}$ & $\begin{array}{l}0,3 \\
3\end{array}$ & 1 & 1 & 1 & 1 & 1 & 1 & 1 & 0,2 & $\begin{array}{l}0, \\
33\end{array}$ & 1 & 1 & 1 & 1 & 1 & 1 & 1 & 1 & 1 & 1 & 1 & 1 & 1 & 1 & 1 & 1 & 1 & 1 & 1 \\
\hline $\begin{array}{l}\mathrm{C} \\
1 \\
0\end{array}$ & 1 & 1 & 1 & 1 & 1 & 1 & $\begin{array}{l}0, \\
2\end{array}$ & $\begin{array}{l}0, \\
33\end{array}$ & 1 & $\begin{array}{l}0, \\
2\end{array}$ & $\begin{array}{l}0,3 \\
3\end{array}$ & 1 & 1 & 1 & 1 & 1 & 1 & 1 & 1 & 1 & 1 & 1 & 1 & 1 & 1 & 1 & 1 & 1 & 1 & 1 & 1 & 1 & 1 & 1 & 1 & 1 & 1 & 1 & 1 \\
\hline $\begin{array}{l}\mathrm{C} \\
1 \\
1\end{array}$ & $\begin{array}{l}0 \\
2 \\
2\end{array}$ & $\begin{array}{l}0, \\
33\end{array}$ & 1 & 1 & 1 & 1 & $\begin{array}{l}0, \\
2\end{array}$ & $\begin{array}{l}0, \\
33\end{array}$ & 1 & $\begin{array}{l}0, \\
2\end{array}$ & $\begin{array}{l}0,3 \\
3\end{array}$ & 1 & $\begin{array}{l}0, \\
2\end{array}$ & $\begin{array}{l}0,3 \\
3\end{array}$ & 1 & 1 & 1 & 1 & 1 & 1 & 1 & 1 & 1 & 1 & 1 & 1 & 1 & 1 & 1 & 1 & 1 & 1 & 1 & 1 & 1 & 1 & 1 & 1 & 1 \\
\hline $\begin{array}{l}\mathrm{C} \\
1 \\
2 \\
\end{array}$ & 1 & 1 & 1 & $\begin{array}{l}0, \\
2\end{array}$ & $\begin{array}{l}0, \\
33\end{array}$ & 1 & $\begin{array}{l}0, \\
2\end{array}$ & $\begin{array}{l}0, \\
33\end{array}$ & 1 & $\begin{array}{l}0, \\
2\end{array}$ & $\begin{array}{l}0,3 \\
3\end{array}$ & 1 & 1 & 1 & 1 & $\begin{array}{l}0, \\
2\end{array}$ & $\begin{array}{l}0,3 \\
3\end{array}$ & 1 & $\begin{array}{l}0,1 \\
1\end{array}$ & $\begin{array}{l}0, \\
14\end{array}$ & $\begin{array}{l}0, \\
2\end{array}$ & 1 & 1 & 1 & 1 & 1 & 1 & 1 & 1 & 1 & 1 & 1 & 1 & 1 & 1 & 1 & 1 & 3 & 5 \\
\hline $\begin{array}{l}\mathrm{C} \\
1 \\
3\end{array}$ & 1 & 1 & 1 & 1 & 1 & 1 & $\begin{array}{l}0, \\
2\end{array}$ & $\begin{array}{l}0, \\
33\end{array}$ & 1 & $\begin{array}{l}0, \\
2\end{array}$ & $\begin{array}{l}0,3 \\
3\end{array}$ & 1 & $\begin{array}{l}0, \\
2\end{array}$ & $\begin{array}{l}0,3 \\
3\end{array}$ & 1 & $\begin{array}{l}0, \\
2\end{array}$ & $\begin{array}{l}0,3 \\
3\end{array}$ & 1 & 1 & 1 & 1 & 1 & 1 & 1 & 1 & 1 & 1 & 1 & 1 & 1 & 1 & 1 & 1 & $\begin{array}{l}0, \\
2\end{array}$ & $\begin{array}{l}0, \\
33\end{array}$ & 1 & 1 & 1 & 1 \\
\hline
\end{tabular}

TABLE. III. NORMALIZED IMPORTANCE WEIGHT

\begin{tabular}{|l|l|l|l|l|l|l|l|l|l|l|l|l|l|}
\hline & $\mathrm{d}(\mathrm{A} 1)$ & $\mathrm{d}(\mathrm{A} 2)$ & $\mathrm{d}(\mathrm{A} 3)$ & $\mathrm{d}(\mathrm{A} 4)$ & $\mathrm{d}(\mathrm{A} 5)$ & $\mathrm{d}(\mathrm{A} 6)$ & $\mathrm{d}(\mathrm{A} 7)$ & $\mathrm{d}(\mathrm{A} 8)$ & $\mathrm{d}(\mathrm{A} 9)$ & $\mathrm{d}(\mathrm{A} 10)$ & $\mathrm{d}(\mathrm{A} 11)$ & $\mathrm{d}(\mathrm{A} 12)$ & $\mathrm{d}(\mathrm{A} 13)$ \\
\hline W & 0,1234 & 0,0842 & 0,1279 & 0,1379 & 0,0478 & 0,0948 & 0,0870 & 0,0478 & 0,0468 & 0,0489 & 0,0468 & 0,0610 & 0,0457 \\
\hline
\end{tabular}

TABLE. IV. WEIGHT OF BENEFIT CATEGORY

\begin{tabular}{|l|l|l|}
\hline & Benefit Category & Weight \\
\hline C1 & Reducing Cost & 0,1234 \\
\hline C2 & Increasing Productivity & 0,0842 \\
\hline C3 & Accelerating Process & 0,1279 \\
\hline C4 & Reducing Risk & 0,1379 \\
\hline C5 & Increasing Revenue & 0,0478 \\
\hline C6 & Increasing Accuracy & 0,0948 \\
\hline C7 & Accelerating Cash-in & 0,0870 \\
\hline C8 & Increasing External Services & 0,0478 \\
\hline C9 & Increasing Image & 0,0468 \\
\hline C10 & Increasing Quality & 0,0489 \\
\hline C11 & Increasing Internal Services & 0,0468 \\
\hline C12 & Increasing Competitive Advantage & 0,0610 \\
\hline C13 & Avoiding Cost & 0,0457 \\
\hline
\end{tabular}

TABLE. V. SPAN BENEFIT SCORE

\begin{tabular}{|l|l|l|l|l|}
\hline & Benefit Category & Score & $\begin{array}{l}\text { Weigh } \\
\text { t }\end{array}$ & $\begin{array}{l}\text { Weighted } \\
\text { Score }\end{array}$ \\
\hline 1 & Reducing Cost & 72,28 & 0,1234 & 8,9192 \\
\hline 2 & Increasing Productivity & 77,00 & 0,0842 & 6,4848 \\
\hline 3 & Accelerating Process & 78,67 & 0,1279 & 10,0629 \\
\hline 4 & Reducing Risk & 78,11 & 0,1379 & 10,7722 \\
\hline 5 & Increasing Revenue & 71,48 & 0,0478 & 3,4175 \\
\hline 6 & Increasing Accuracy & 80,90 & 0,0948 & 7,6684 \\
\hline 7 & Accelerating Cash-in & 79,83 & 0,0870 & 6,9468 \\
\hline 8 & Increasing External Services & 75,16 & 0,0478 & 3,5933 \\
\hline 9 & Increasing Image & 76,32 & 0,0468 & 3,5682 \\
\hline 10 & Increasing Quality & 79,00 & 0,0489 & 3,8639 \\
\hline 11 & Increasing Internal Services & 76,00 & 0,0468 & 3,5534 \\
\hline 12 & Increasing Competitive Advantage & 68,92 & 0,0610 & 4,2016 \\
\hline 13 & Avoiding Cost & 72,94 & 0,0457 & 3,3370 \\
\hline & Total & $\mathbf{7 5 , 8 9}$ & & $\mathbf{7 6 , 3 9}$ \\
\hline
\end{tabular}


TABLE. VI. SAKTI BENEFIT SCORE

\begin{tabular}{|l|l|l|l|l|}
\hline & Benefit Category & Score & $\begin{array}{l}\text { Weigh } \\
\text { t }\end{array}$ & $\begin{array}{l}\text { Weighted } \\
\text { Score }\end{array}$ \\
\hline 1 & Reducing Cost & 63,43 & 0,1234 & 7,8275 \\
\hline 2 & Increasing Productivity & 68,98 & 0,0842 & 5,8097 \\
\hline 3 & Accelerating Process & 71,64 & 0,1279 & 9,1643 \\
\hline 4 & Reducing Risk & 71,03 & 0,1379 & 9,7958 \\
\hline 5 & Increasing Revenue & 57,75 & 0,0478 & 2,7611 \\
\hline 6 & Increasing Accuracy & 75,55 & 0,0948 & 7,1610 \\
\hline 7 & Accelerating Cash-in & 66,43 & 0,0870 & 5,7807 \\
\hline 8 & Increasing External Services & 62,91 & 0,0478 & 3,0077 \\
\hline 9 & Increasing Image & 64,36 & 0,0468 & 3,0093 \\
\hline 10 & Increasing Quality & 70,05 & 0,0489 & 3,4260 \\
\hline 11 & Increasing Internal Services & 70,98 & 0,0468 & 3,3185 \\
\hline 12 & Increasing Competitive Advantage & 64,00 & 0,0610 & 3,9015 \\
\hline 13 & Avoiding Cost & 68,13 & 0,0457 & 3,1167 \\
\hline & Total & $\mathbf{6 7 , 3 3}{ }^{\text {b }}$ & & $\mathbf{6 8 , 0 8}$ \\
\hline
\end{tabular}

The similar results gained for SAKTI investment. The total weighted benefit score $(68.08 \%)$ is higher than the original score $(67.33 \%)$. It also indicates that some benefit categories with high priority has a higher score among others. The top priority benefit category (reducing risk) got score $71.03 \%$ that categorized as high benefit. While the least score of benefit category belongs to benefit "increasing revenue" with score of $57.75 \%$ that categorized as a medium benefit.

From those two IT investments, the final score of the benefit creation is categorized as "high benefits". This category still can be improved to become a "very high benefits" category. The leader of the organization could use the results of these measurements as a base for evaluation to improve the achievement of IT investment benefits.

\section{CONCLUSION AND FUTURE WORK}

Based on the result and discussion, the proposed model could fulfill the research objectives. First, the model can overcome the problem of differences in the benefits criteria between organizations and can measure the benefits created from an IT investment in government organizations. Second, the differences between the score using FAHP weighting and the original score indicates that the model accommodates the organization's preference in the evaluation. Third, the proposed model can be a supporting tool to meet the requirements of COBIT 5 framework, especially in the EDM02 process Ensure Benefits Delivery.

For future work, researchers can develop new business value templates that are better suited to the nature of government organizations. In addition, researchers can also try other weighting methods and compare the results with the results of the Fuzzy AHP method.

\section{ACKNOWLEDGMENT}

The authors would like to thank all the respondents and the decision maker in the Ministry of Finance for their time and effort to help complete this research.

\section{REFERENCES}

[1] Bertot, J. C., Jaeger, P. T., and Grimes, J. M., "Using ICTs to create a culture of transparency : E-government and social media as openness and anti-corruption tools for societies." Government Information Quarterly 27 (2010) pp. 264-271

[2] Willcocks, L., and Lester, S., "Beyond the IT Productivity Paradox," European Management Journal Vol. 14, No.3, pp. 279-290, 1996.

[3] Ballantine, J.A., Galliers, R.D., and Stray, S.J., "Information system/technology evaluation practices: evidence from UK organizations," Journal of Information Technology (1996) 11, 129-141.

[4] Norris, G., "Post-investment Appraisal - Investing in Information Systems: Evaluation and Management," Chapman and Hall, London, 1996.

[5] Hillam, C., Edwards, H., and Young, C., "Company approaches to IT/IS investment and the resulting evaluation," Seventh European Conference on Information Technology Evaluation, Brown, A., and Remenyi, D. (eds), Trinity College, Dublin, Ireland, pp.109-116, 2000.

[6] Bannister, F., and Remenyi, D., "Value perception in IT Investment Decisions," The Electronic Journal of Information Systems Evaluation, Vol. 2, No. 2, 1999.

[7] Dadayan, L., "Measuring Return on Government IT Investments," Proceeding of European Conference on Information Technology Evaluation, Genoa, 2006.

[8] Palka, W., Gülümser, Y., Jurisch, M.C., Wolf, P. dan Krcmar, H., "Basic Approaches for the Evaluation of IT-Investments in E-Government: A Literature Review," Electronic Government and Electronic Participation - Joint Proceedings of Ongoing Research of IFIP EGOV and IFIP ePart 2014, Gesellschaft für Informatik e.V., Bonn, pp. 27-34, 2014.

[9] AL-Ghamdi, A.S.A., Saleem, F., "General Characteristics and Common Practices for ICT Projects: Evaluation Perspective", International Journal of Advanced Computer Science and Applications Vol.9 No.1, 2018.

[10] Setiawan, H., Istiyanto, J.E., Wardoyo, R., Santoso, P., "The Group Decision Support System To Evaluate The ICT Project Performance Using The Hybrid Method Of AHP, TOPSIS And Copeland Score", International Journal of Advanced Computer Science and Applications Vol.7 No.4, 2016.

[11] Ranti, B., "The Generic IS/IT Business Value Category : Cases in Indonesia," Konferensi dan Temu Nasional TIK Untuk Indonesia, Jakarta, 2008.

[12] Saaty, T.L., "A Scaling method for priorities in hierarchichal structure," Journal of Mathematical Psychology, 15, pp. 234-281, 1977.

[13] Van Laarhoven, P.J.M. dan Pedrycz, W., "A Fuzzy Extension of Saaty's Priority Theory," Fuzzy Sets and Systems (11), pp.229-241, 1983.

[14] Sehra, S.K., Brar, Y.S., Kaur, N., "Application of Multi-Criteria Decision Making in Software Enginering", International Journal of Advanced Computer Science and Applications Vol.7 No.7, 2016.

[15] Chang, D.Y., "Applications of the extent analysis method on fuzzy AHP," European Journal od Operational Research 95, pp. 649-655, 1996.

[16] Saaty, T.L., "How to make a decision: The Analytic Hierarchy Process," European Journal of Operational Research 48, pp. 9-26, 1990.

[17] Davison, R.M., "A Survey of Group Support Systems: Technology and Operation," City University of Hong Kong, China. Sprouts: Working Papers on Information Systems, 1(12), 2001. 